\title{
Application of Vegetation Indexes to Assess the Condition of Crops
}

\section{Rashid K. Kurbanov,}

$\mathrm{Ph} . \mathrm{D}$.(Eng.), leading researcher, e-mail: smedia@vim.ru;
Natalya I. Zakharova,

graduate student

Federal Scientific Agroengineering Center VIM, Moscow, Russian Federation

\begin{abstract}
Monitoring of the state of agricultural crops and forecasting the crops development begin with aerial photography using a unmanned aerial vehicles and a multispectral camera. Vegetation indexes are selected empirically and calculated as a result of operations with values of different spectral wavelengths. When assessing the state of crops, especially in breeding, it is necessary to determine the limiting factors for the use of vegetation indexes. (Research purpose) To analyze, evaluate and select vegetation indexes for conducting operational, high-quality and comprehensive monitoring of the state of crops and the formation of optimal management decisions. (Materials and Methods) The authors studied the results of scientific research in the field of remote sensing technology using unmanned aerial vehicles and multispectral cameras, as well as the experience of using vegetation indexes to assess the condition of crops in the precision farming system. The limiting factors for the vegetation indexes research were determined: a limited number of monochrome cameras in popular multispectral cameras; key indicators for monitoring crops required by agronomists. After processing aerial photographs from an unmanned aerial vehicle, a high-precision orthophotomap, a digital field model, and maps of vegetation indexes were created. (Results and discussion) More than 150 vegetation indexes were found. Not all of them were created through observation and experimentation. The authors considered broadband vegetation indexes to assess the status of crops in the fields. They analyzed the vegetation indexes of soybean and winter wheat crops in the main phases of vegetation. (Conclusions) The authors found that each vegetative index had its own specific scope, limiting factors and was used both separately and in combination with other indexes. When calculating the vegetation indexes for practical use, it was recommended to be guided by the technical characteristics of multispectral cameras and took into account the index use effectiveness at various vegetation stages.
\end{abstract}

Keywords: digital farming, remote sensing, crop monitoring, unmanned aerial vehicle, vegetation indexes, multispectral cameras, aerial photography, vegetation map of crops.

For citation: Kurbanov R.K., Zakharova N.I. Primenenie vegetatsionnykh indeksov dlya otsenki sostoyaniya sel'skokhozyaystvennykh kul'tur [Application of vegetation indexes to assess the condition of crops]. Sel'skokhozyaystvennye mashiny i tekhnologii. 2020. Vol. 14. N2. 4-11 (In English). DOI 10.22314/2073-7599-2020-14-4-4-11.

\section{Применение вегетационных индексов для оценки состояния сельскохозяйственных культур}

\author{
Рашид Курбанович Курбанов, \\ кандидат технических наук, \\ ведущий научный сотрудник, \\ e-mail: smedia@vim.ru;
}

\author{
Наталья Ивановна Захарова, \\ аспирант
}

Федеральный научный агроинженерный центр ВИМ, Москва, Российская Федерация

Реферат. Аэрофотосъемку с помощью беспилотных летательных аппаратов и мультиспектральной камеры применяют для мониторинга состояния посевов и прогноза развития сельскохозяйственных культур. В результате операций со значениями различных спектральных длин волн эмпирически подбирают и рассчитывают вегетационные индексы, составляя карты. При оценке состояния посевов необходимо определять лимитирующие факторы применения вегетационных индексов. (Цель исследования) Проанализировать, оценить и выбрать вегетационные индексы для проведения оперативного, качественного и комплексного мониторинга состояния сельскохозяйственных культур и формирования оптимальных управленческих решений. (Материалы и методы) Изучили результаты научных исследований в области технологий дистанционного зондирования с использованием беспилотных летательных аппаратов и мультиспектральных камер, а также опыт применения вегетационных индексов для оценки состояния сельскохозяйственных культур в системе точного земледелия. Определили лимитирующие факторы для исследования вегетационных индексов: ограниченное количество 
монохромных камер в популярных мультиспектральных камерах; основные показатели для мониторинга сельскохозяйственных культур, необходимые агрономам. После обработки аэрофотоснимков с беспилотного летательного аппарата создали высокоточный ортофотоплан, цифровую модель поля и карты вегетационных индексов. (Результаты и обсуждение) Обнаружили более 150 вегетационных индексов. Не все их них создавались путем наблюдений и экспериментов. Рассмотрели широкополосные вегетационные индексы для оценки состояния посевов на полях. Проанализировали вегетационные индексы посевов сои и озимой пшеницы в основных фазах вегетации. (Bblводыl) Выявили, что каждый вегетационный индекс имеет свою специфическую сферу применения, ограничивающие факторы и используется как отдельно, так и в комплексе с другими индексами. Рекомендовали при расчете вегетационных индексов для практического применения руководствоваться техническими характеристиками мультиспектральных камер и учитывать эффективность применения индекса на различных стадиях вегетации.

Ключевые слова: цифровое земледелие, дистанционное зондирование, мониторинг посевов, беспилотный летательный аппарат, вегетационные индексы, мультиспектральные камеры, аэрофотосъемка, вегетационная карта посевов.

$\mathrm{R}$ emote probing is one of the rapidly developing areas of monitoring the state of the field and plants in order to obtain information necessary for further analysis and the formation of effective management decisions. This technology allows you to measure soil characteristics, crops and water resources using unmanned aerial vehicles (UAVs), airplanes and satellites in precision agriculture [1]. It is based on the interaction of electromagnetic radiation with soil, vegetation or other biological object (Fig. 1). The use of remote probing tools is mainly used to assess the plants state: growth, dynamics of green phytomass development (normalized difference vegetation index NDVI, leaf area index LAI), vegetation density, yield potential, as well as to detect and map biotic (insects, weeds, etc. disease) and abiotic (lack of water, lack of mineral and organic substances) stress [2].

High-resolution imaging by remote probing from satellites and aerial platforms can be limited by the cloud layer. Land cover makes it difficult to collect soil data. The spatial resolution also plays a significant role [3]. As this indicator improves, the area of the smallest pixel decreases, and the uniformity of soil or crop characteristics in this pixel increases. A lower spatial resolution means larger pixel sizes and increased heterogeneity in soil and plant characteristics.

The UAV, complete with suspended equipment such as the MicaSense Altum or Parrot Sequoia, allows highly accurate crops monitoring. It becomes possible, on the basis of aerial surveys, to assess the density of seedlings, foci of plant damage and observe the development of processes in dynamics. After processing the aerial survey data, vegetation indexes are calculated and maps of these indexes are generated. The vegetation index is a relative indicator that determines the presence or absence of vegetation cover and evaluates its viability. Vegetation indexes are used not only for monitoring agricultural crops, but also for studying arid regions, forests, environmental changes, the impact of biotic and abiotic stresses on agricultural biological objects [4-10].

Research purpose is to analyze, evaluate and select vegetation indexes for conducting operational, high-quality and comprehensive monitoring of the state of crops

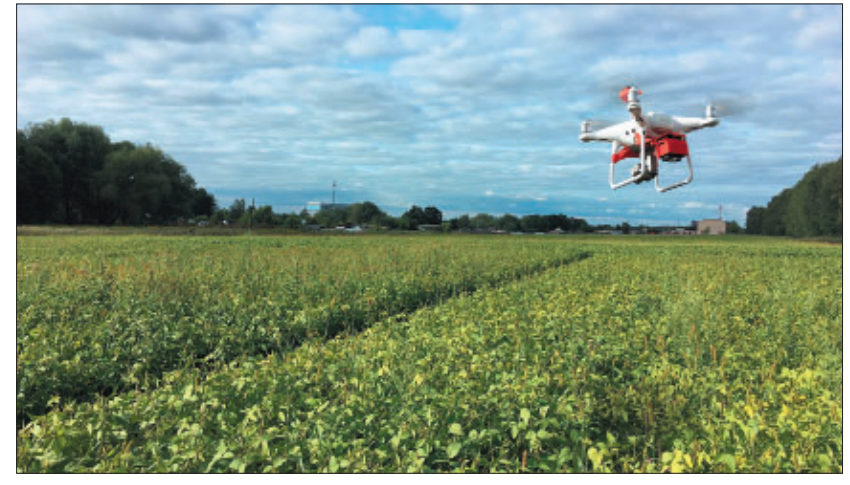

Fig. 1. Monitoring of soybean crops from UAVS

and the formation of optimal management decisions.

Materials AND methods. Using the method of comparative analysis, the authors studied the results of scientific research and reviews on the use of vegetation indexes to obtain information on the agricultural crops state in the precision farming system. They considered modern achievements and developments in the field of remote sensing technologies using UAVs for assessing the agricultural biological objects state using vegetation indexes. They identified limiting factors for the study of vegetation indexes:

- a limited number of monochrome cameras of popular multispectral cameras: red (Red), extreme red (RedEdge), infrared (NIR), blue (Blue), green (Green) channels;

- the main indicators for monitoring agricultural crops required by agronomists (biomass volume, nitrogen concentration, chlorophyll content in plant leaves, leaf area, etc.).

Aerial photography was carried out in the Ryazan Region in the breeding fields of soybeans and winter wheat using a DJI Phantom 4 pro quadcopter and a Parrot Sequoia multispectral camera in April-August 2019. Weather data were recorded daily by the local weather station. Multispectral data were processed using Pix4DMapper software.

After processing aerial photographs from the UAV, a high-precision orthophotomap, a field digital model and maps of vegetation indexes for selection soybeans and 
winter wheat crops were created.

Results and discussion. Remote probing of agricultural biological objects is based on spectral channels available for shooting (Fig. 2):

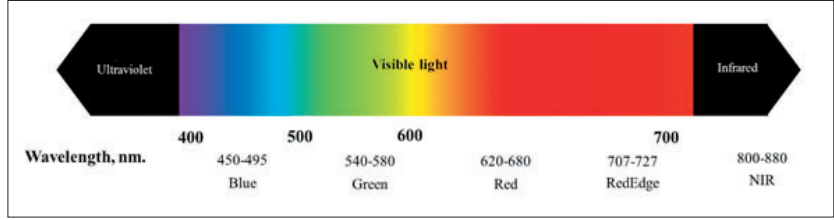

Fig.2. Spectral channels

- blue (Blue) - 450-495 nm;

- green (Green) - 540-580 nm;

- red (Red) - 620-680 nm;

- extreme red (RedEdge) - 707-727 nm;

- near infrared (NIR) - 800-880 nm.

Radiation, reflection or scattering of electromagnetic waves depends on the chemical and morphological properties of biological objects. Near and middle infrared channels are used to assess characteristics that go beyond quantifying plant growth and biomass, namely, those related to the content of water, pigments, sugar and aromatic substances [11]. Therefore, the indexes developed in the last decade are applicable for monitoring the water potential of plants and the levels of abiotic and biotic stresses [9, 10]. The vegetation index is a metric calculated by transforming data from multiple spectral channels in each pixel of the resulting images. When using high-resolution spectral devices, the number of channels received by remote sensing increases, and the transmission channel becomes narrower. The most popular multispectral cameras for monitoring agricultural crops using UAVs include Parrot Sequoia, RedEdge-MX, MicaSense Altum, Sentera Quad Sensor, Sentera Double 4K, Sentera 6X Multispectral Sensor (Fig. 3).

The combination of serial commercial drones, multispectral cameras and modern software for processing received aerial photographs allows the development of powerful platforms for solving many important problems in agriculture, such as monitoring agricultural biological objects and the environment [12-14].

More than 150 vegetation indexes are mentioned in the scientific literature, calculated from data in wide and narrow spectral channels. The broadband spectral index equations use the Red or NIR channels. Multispectral cameras consist of monochrome cameras with different centers of spectral channels and their width, therefore, when calculating vegetation indexes, it is necessary to be guided by the documentation about the camera used. For example, Parrot Sequoia shoots in NIR in the $750-830 \mathrm{~nm}$ range with a channel center at $790 \mathrm{~nm}$, while the MicaSense Altum has a $800-880 \mathrm{~nm}$ range for this channel with a center at $840 \mathrm{~nm}$. Only a small part of the vegetation indexes is verified experimentally or has a significant biophysical basis.

Most vegetation indexes are calculated based on the

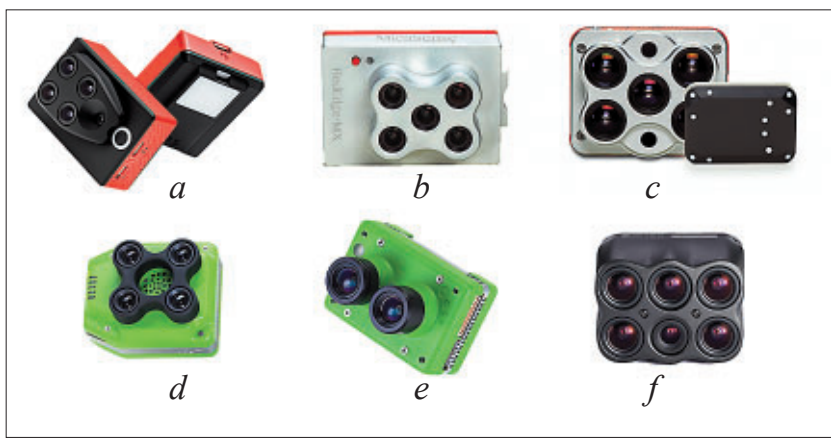

Fig. 3. Popular models of multispectral cameras:

$a$ - Parrot Sequoia; $b$ - RedEdge-MX; c - MicaSense Altum; $d$-Sentera Quad Sensor; e - Sentera Double 4K; $f$-Sentera $6 X$ Multispectral Sensor

two most stable (independent of other factors) spectral ranges - Red and NIR. The first is the maximum absorption of solar radiation by chlorophyll, and the second is the maximum reflection of plant energy. High photosynthetic activity, usually associated with a large phytomass of vegetation, leads to reduced reflectivity in the red channel and high values in the near infrared channel.

According to the spectral signature, green vegetation has very low reflectivity in the Red and Blue channels and high reflections in the Green, so the vegetation appears green. However, the reflectance is relatively higher in NIR. At the same time, the Blue channel is more sensitive to the presence of suspended microparticles in the air, due to its shorter wavelength compared to Red. The ratio of these indicators makes it possible to classify vegetation and other objects [15].

One of the first vegetation indexes published in the scientific literature was the Ratio Vegetation Index (RVI) proposed by K.F. Jordan in 1969 [16]. It is also called Simple Ratio Index - SR and is used for quick assessment of biological objects. The RVI Index (SR) has become one of the most readily available vegetation indexes. It represents the ratio between the reflectivity of vegetation in the NIR and Red channels:

$$
R V I(S R)=\frac{N I R}{R e d},
$$

where NIR - near infrared reflection;

Red - red reflection.

As a result of simulations carried out by Japanese scientists, it is revealed that RVI (SR) is sensitive to solar radiation [17]. Its value is close to 1 if the object under study has the same reflection in both the Red and NIR channels, for example, soil. At the same time, the index value for green vegetation will be above 1 .

This index is useful when you need to estimate quickly the relative vegetation biomass, distinguish green vegetation from other features on the map, or identify areas of low/high density of vegetation cover.

When monitoring agricultural biological objects, the Normalized Difference Vegetation Index (NDVI) is often used [18]. It is calculated from multispectral survey 
data as the normalized ratio between Red and NIR channels:

$$
N D V I=\frac{N I R-R e d}{N I R+R e d}
$$

This index is suitable for monitoring the yield throughout the growing season. The direct use of the index is to detect and assess the intensity of the plants vegetation. NDVI takes values from -1 to 1 . Green vegetation has positive NDVI values: the more green phytomass, the higher the index.

Using the NDVI vegetation maps, in the selection fields at the first stages of the soybean vegetation, areas with uneven seedlings, vegetation with a small amount of phytomass, areas with a large number of weeds (problem areas) are identified (Fig. 4).

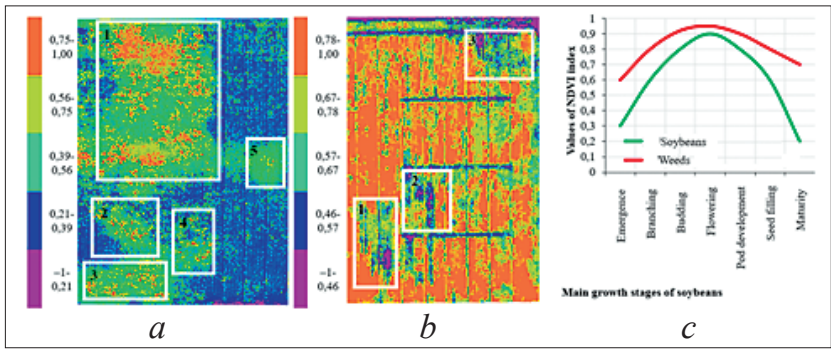

Fig. 4. NDVI vegetation map of soybean, aerial photography from the DJI Phantom 4 pro and multispectral camera Parrot Sequoia: a-aerial photography at emergence phase from May 29, 2019;

$b$ - aerial photography at budding and flowering phases of July 2, 2019; c - chart of average NDVI values for the main growth stages of soybeans

Aerial photography is made using a DJI Phantom 4 pro and a Parrot Sequoia multispectral camera. On sites 1-5, weeds are visible, the NDVI of which is $0.39-1$. In the germination phase, the soybean crop index does not exceed 0.4 , and during the budding and flowering period - more than 0.8 . At these growing season stages, according to NDVI maps, problem areas 1-3 with a small amount of phytomass in the range of 0.57 and below are found (Fig. $4 b$ ). At the growing season final stages, the maps analysis makes it possible to determine the readiness of the crop for harvesting, as well as the presence of weeds. The curves of average NDVI values for the main phases of the growing season of soybeans in comparison with weeds differ (Fig. 4c). The graph shows that the NDVI index allows you to separate weeds from soybeans in the initial and final phases of the growing season. The authors do not recommend using the NDVI index when examining sparse and dense vegetation. The NDVI is sensitive to soil and aerosol atmospheric pollution, so additional indexes will be required for more accurate vegetation analysis.

NDVI vegetation maps, based on aerial photographs from UAVs, were used in a study by scientists from China to estimate biomass, predict yields and select breeding wheat varieties. The authors studied 32 wheat varieties grown under conditions of limited and complete irriga- tion [19]. Scientists also used the index to assess crops under the influence of abiotic stresses, for example, for phenotyping corn crops with a lack of nitrogen [10].

The level of air pollution, evaporation from the vegetation and soil cover surface changes during the day, especially in areas with sharp elevation changes, for example, in vineyards. Microparticles in the air, just like agricultural biological objects, are capable of emitting, reflecting or scattering electromagnetic waves. They cause errors in the calculation of vegetation indexes, including the NDVI index. To reduce such errors, it is advisable to use indexes that are resistant to aerosol pollution of the atmosphere and reflections of the soil cover, calculated mainly when using the blue channel. For example, the MicaSense Altum multispectral camera has the Blue channel in the range of 455-495 nm. Fog, dust, smog, air pollution distort aerial photography data. The main reason the Blue channel is more susceptible to sources of aerosol pollution than Red, is because of its short wavelength. Generally, the shorter the wavelength, the stronger the scattering. The indexes resistant to aerosol pollution of the atmosphere include:

- Atmospherically Resistant Vegetation Index - ARVI, used to estimate phytomass at average values of vegetation cover density, calculation by RGB data is possible;

- Enhanced Vegetation Index - EVI, used to assess phytomass at high density of vegetation cover, has a high correlation with Leaf Area Index - LAI;

- Structure Insensitive Pigment Index - SIPI, suitable for identifying plant diseases at early stages, as well as for detecting hydrocarbon deposits $[11,20]$.

In the germination phase, the vegetation cover is sparse, there are open soil areas. In the final stages of the growing season, when assessing crops before harvesting, the vegetation also becomes thinner. In such a situation, due to the high degree of crops sparseness and the strong influence of the soil, NDVI is ineffective in the analysis of plant phytomass. To eliminate some of the limitations of the NDVI, the Modified Soil Adjusted Vegetation Index (MSAVI) and its later version, MSAVI2, are used.

The problem with the original Soil Adjusted Vegetation Index (SAVI) is that it requires trial and error to determine the soil brightness correction factor $(L)$ based on the amount of vegetation in the study area. When calculating SAVI, the default value $\mathcal{L}=0.5$ was usually used, which distorted the obtained data. In 1994, scientists developed a modified index to facilitate a simple and reliable calculation [21]:

$$
\text { MSAVI2 }=\frac{2 \cdot N I R+1-\sqrt{(2 \cdot N I R+1)^{2}-8 \cdot(N I R-R e d)}}{2} .
$$

The MSAVI2 index takes into account the reflections of open soil areas and is used to study biological objects with a sparse vegetation cover, for example, in the early or final stages of crop vegetation.

In the middle of the growing season, healthy plants de- 
velop and gain biomass, the density of the vegetation cover often exceeds $80 \%$. With such a density, the most popular NDVI index turns out to be uninformative. The indexes assessing the plant cover photosynthetic activity are more sensitive to changes in the plant chlorophyll and give a detailed picture of the crops state. Chlorophyll content reflects the physiological state of vegetation. It decreases in stressful situations. Therefore, the estimate of the chlorophyll amount can be used as a plant health indicator.

In the scientific literature, there are many vegetation indexes for assessing the photosynthetic activity of vegetation. In remote sensing, the following broadband vegetation indexes are used to assess the chlorophyll content in the leaves of different plant species [22-25]:

- Normalized Difference Red Edge Index - NDRE;

- Green chlorophyll index - ClGreen (GCI);

- Green leaf index - GLI;

- Canopy Chlorophyll Content Index - CCCI;

- Green Normalized Difference Vegetation Index GNDVI;

- Chlorophyll vegetation index - CVI;

- Leaf Area Index - LAI.

The narrow-band Modified Chlorophyll Absorption in Reflectance Index - MCARI [11] is referred to adapted for broadband indexes. In the adapted formula, the narrow-spectrum p670 channel is replaced with a broadband RedEdge. The index reacts to minimal changes in chlorophyll and is used to estimate leaf area, as it has a high correlation with LAI.

The Normalized Difference Red Edge Index (NDRE) is suitable for assessing the photosynthetic activity of the vegetation cover and the leaves saturation with nitrogen. It can be calculated only if there is a RedEdge channel [22]:

$$
N D R E=\frac{N I R-R e d E d g e}{N I R+R e d E d g e},
$$

where RedEdge - extreme red reflection.

Compared to the red channel, it penetrates the leaf better and is less absorbed by chlorophyll in the first layers of the leaf. The RedEdge canal is very sensitive to medium and high chlorophyll levels and is considered a good indicator of the selection crop health during the growing season when there is a relatively high concentration of chlorophyll in the leaves. In addition, the NDRE evaluates the nitrogen concentration in plant leaves, which contributes to the recommendations for nitrogen fertilization. The index varies from -1 to 1 . Green vegetation corresponds to NDRE values above zero: the higher the nitrogen concentration in plant leaves, the higher the index.

When assessing the soybean crops state at the main stages of the growing season, NDRE made it possible to identify areas with depressed vegetation, with a minimum nitrogen content in the leaves (Fig. 5). An analysis of the NDRE vegetation map dated June 20, 2019 in the budding phase and at the beginning of the flowering phase revealed abnormally low, close to zero indicators of nitrogen con- tent in soybean leaves: variants $1 b, 2 b$, and $3 b$. Normally, crops take such values a few days before harvesting. When analyzing the NDRE vegetation map, orthophotomap sites $1 a, 2 a$ and $3 a$, the results of soil samples and data from weather conditions, it was noted that the crops were in a depressed state. They could not consume macro- and micronutrients due to high temperatures and lack of rain for more than 30 days. The falling precipitation improved the physiological characteristics of soybean crops (Fig. 5, NDRE map from 02.07.2019). The NDRE index values $(1 c, 2 c, 3 c)$ approached the norm - 0.3-0.4 for the considered phases of the soybean growing season.

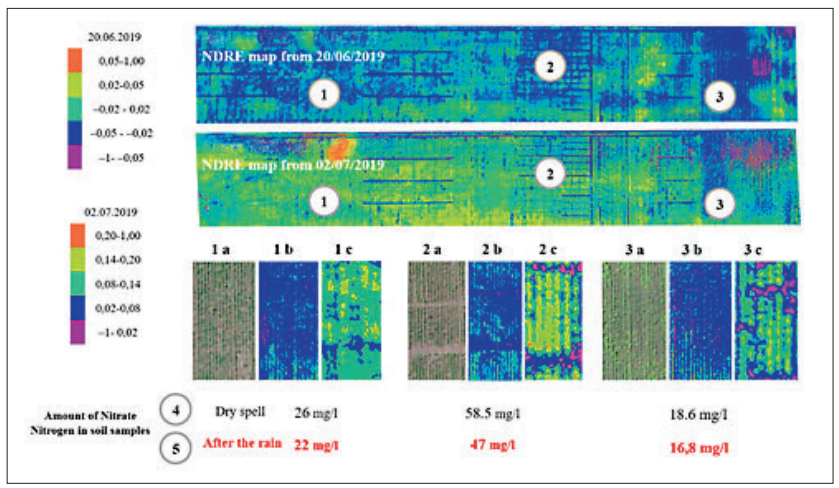

Fig. 5. NDRE vegetation maps of soybean, aerial photography from the DJI Phantom 4 pro and multispectral camera Parrot Sequoia

1a, 2a, 3a-areas of ortophotoplan from June 20, 2019 at the places where soil samples were taken

$1 b, 2 b, 3 b$-areas of NDRE vegetation map from June 20, 2019 at the places where soil samples were taken

$1 c, 2 c, 3 c$-areas of NDRE vegetation map from July 2, 2019 at the places where soil samples were taken

4 - concentration of Nitrogen in soil samples from June 20, 2019

5 - concentration of Nitrogen in soil samples from July 2, 2019

There was practically no precipitation from 01.06 to 23.06 in 2019 (Fig. 6). Ground observations of breeders showed the absence of a depressed or stressful state of soybean crops in the phases of branching, budding, and the beginning of flowering. However, according to aerial photography, the average NDRE values for the field during this period decreased from 0.18 to 0 . The precipitation $-46.7 \mathrm{~mm}$ in the period from 24.06 to 15.07 - contributed to an increase in the average NDRE value over the field to 0.28 . During a drought, nitrogen in the soil was in an inactive form and was not assimilated by plants. Its nitrogen lack disrupted plant growth and also causes yellowing due to insufficient chlorophyll formation. The visual assessment of the plants state did not accurately reflect the current situation. Analysis of the NDRE vegetation map promptly revealed the stress state of soybean crops before the appearance of visual deviations.

The authors recommend using the index on both sparse and dense crops, where the density of the vegetation cover is more than $80 \%$. 


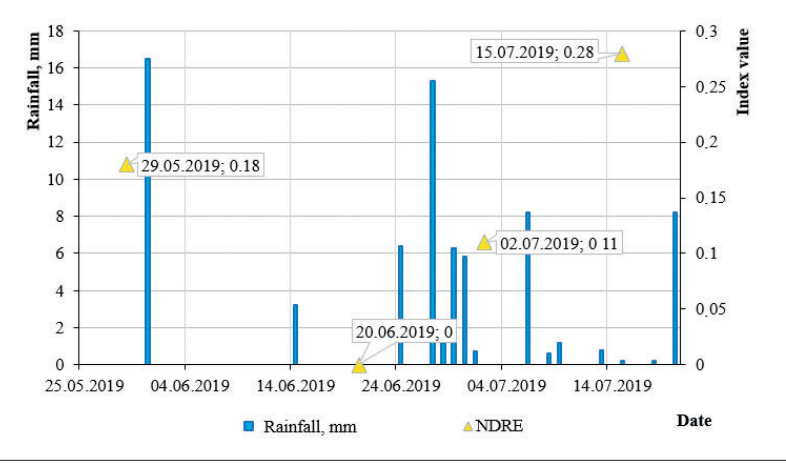

Fig. 6. Dependences of average NDRE data on amount of precipitation

Scientists at an experimental farm at Niigata University in Japan compared the NDRE and NDVI vegetation indexes. As a result, it was found that NDVI was more effective for analyzing large crops areas, determining the density of vegetation cover, assessing the health of crops and seeding rates. While NDRE allowed visualizing the chlorophyll content in leaves, identifying problem areas where additional nitrogen fertilization was required, or areas oversaturated with nitrogen [26].

Revealing seasonal changes in the photosynthetic potential of agricultural crops is assessed using the relative chlorophyll index (Green chlorophyll index - ClGreen, or GCI) [23]. The total chlorophyll content is linearly correlated with the difference between the mutual reflections of the green and near infrared channels:

$$
\text { ClGreen }(G C I)=\frac{N I R}{\text { Green }}-1,
$$

where Green - green reflection.

The ClGreen Index (GCI) is used to assess the chlorophyll content $a$ and $b$ in leaves, the state of plant nutrients, aging processes and the presence of biotic stresses. ClGreen (GCI) ranges from - 1 and up. If green vegetation with a high content of chlorophyll is in the leaves, then the index value is greater than 4 . For example, in soybean crops, such indicators are achieved at the phases of flowering and fruit formation [27].

Using the maps of vegetation indexes NDVI and ClGreen (GCI), the authors estimated the overwintering of winter wheat crops (Table). Photogrammetric processing of spectral data was carried out in the Pix4dMapper soft- ware. The ranges of values for the NDVI and ClGreen (GCI) were given based on the classification of their vegetation maps. Analysis of the NDVI map showed that areas with healthy seedlings made up 0.18 ha of the total field area. Analysis of the ClGreen (GCI) map revealed areas with healthy seedlings over a larger area -0.31 ha. Ground verification of breeders confirmed the ClGreen (GCI) values. For a reliable assessment of winter wheat overwintering, it was not enough to rely only on the NDVI, since it was not informative on sparse seedlings. ClGreen (GCI) was more sensitive than NDVI to changes in vegetation status, especially at low phytomass values. It evaluates the chlorophyll content in plants more differentially.

The soybean crops analysis in the main phases of the growing season was carried out using a number of indexes. ClGreen (GCI) was informative throughout the growing season and contributed to the assessment of the crops photosynthetic potential, the identification of early maturing varieties and the creation of recommendations for harvesting (Fig. 7). The graph shows how sensitive the ClGreen (GCI) curve is to the slightest changes in plant health, unlike other indexes.

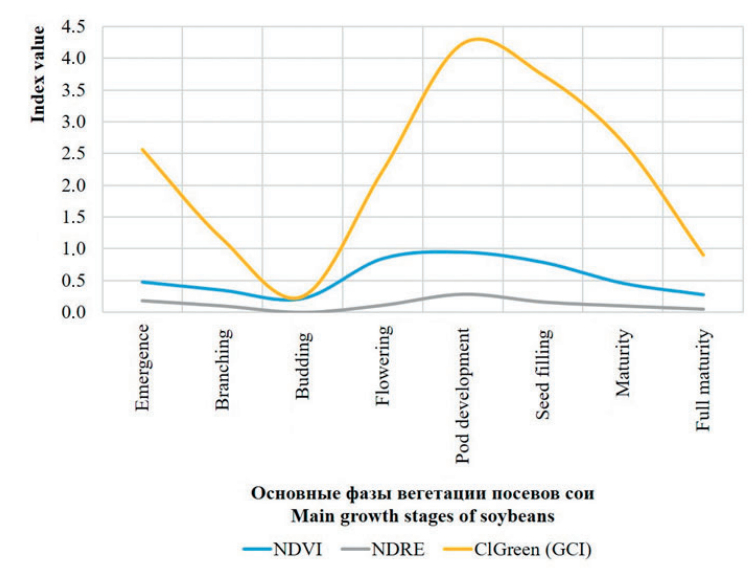

Fig. 7. Average value of NDVI, NDRE u ClGreen (GCI) on the field

The index helps to identify seasonal changes, environmental stresses, the impact of pesticides used on plant health. It is recommended for the analysis of crops during the entire growing season both with sparse vegetation and vegetation with a large amount of phytomass.

\begin{tabular}{|c|c|c|c|c|c|}
\hline \multicolumn{6}{|c|}{ Values of the Vegetation indices $C$ LGReen $(G C l)$ and $N D V I$ for Winter Wheat Crops* } \\
\hline \multicolumn{3}{|c|}{ ClGreen $(G C I)$} & \multicolumn{3}{|c|}{ NDVI } \\
\hline value & square, ha & description & value & square, ha & description \\
\hline $1.61 \ldots 2.03$ & 0.04 & healthy seedlings & $0.55 \ldots 1.0$ & 0.05 & healthy seedlings \\
\hline $1.20 \ldots 1.61$ & 0.09 & healthy seedlings & $0.41 \ldots 0.55$ & 0.13 & healthy seedlings \\
\hline $0.78 \ldots 1.20$ & 0.18 & healthy seedlings & $0.27 \ldots 0.41$ & 0.19 & inhibited seedlings \\
\hline $0.36 \ldots 0.78$ & 0.44 & inhibited seedlings & $0.13 \ldots 0.27$ & 0.46 & inhibited seedlings \\
\hline$-1.00 \ldots 0.36$ & 0.08 & soil & $-1.00 \ldots 0.13$ & 0.00 & soil \\
\hline
\end{tabular}


During the photosynthetic plants activity studies, the following indexes will also be informative:

- GLI helps to assess the plants condition when examining crops using RGB data;

- CCCI is effective for the chlorophyll study and the assessment of nitrogen saturation, at different crop densities;

- CVI - to assess the level of chlorophyll at the initial stages of plant vegetation;

- GNDVI - for assessing aging and withering vegetation, in the absence of RedEdge channel data;

- LAI - for a relative assessment of the crops leaf area.

With a comprehensive crops assessment during the growing season, it is most effective to use several vegetation indexes, depending on the growing season, research goals and camera capabilities. So, when examining crops using RGB data, the GLI index is informative for an overall assessment of the crops state. In the variant with a multispectral camera, monochrome images are examined, and the number of indexes available for calculation increases. If a quick assessment of the vegetation cover density is required, the RVI (SR) should be used. During the entire growing season, it is more rational to use indexes that are resistant to aerosol atmospheric pollution and the effects of the soil cover: EVI, NDRE, ClGreen (GCI), MCARI and LAI. At the initial stages of the growing season, with sparse vegetation and a large influence of soil reflections -
MSAVI, CVI. With a vegetation density of $20-80 \%$, NDVI and ARVI are optimal. In the middle of the development cycle, with a high level of photosynthetic activity and the need for early diseases diagnosis, the CCCI and SIPI indexes are the most differentiated and sensitive to crops changes. When plants are ripe, ready for harvesting and wilting, it is advisable to use the MSAVI and GNDVI indexes.

Conclusions. The vegetation indexes specifics indicate that the need to use one or more of them depends on the tasks of studying agricultural crops and the multispectral cameras capabilities.

On the basis of multispectral data obtained as a result of aerial photography, various vegetation indexes are calculated, which help to assess agricultural crops state, to identify the presence of biotic and abiotic stresses. Depending on the used vegetation index, broadband and narrowband spectral channels are used.

It was found that each vegetation index had its own specific scope, limiting factors and was used both separately and in combination with other vegetation indexes. When calculating vegetation indexes for practical use, one should be guided by the technical characteristics of multispectral cameras and took into account the effectiveness of using the index at different stages of the growing season.

\section{REFERENCES}

1. Adao T, Hruska J., Padua L., Bessa J., Peres E., Morais R., Sousa J.J. Hyperspectral Imaging: A Review on UAV-Based Sensors, Data Processing and Applications for Agriculture and Forestry. Remote Sensing. 2017. Vol.9(11). N1110. DOI:10.3390/ rs9111110 (In English).

2. Tsouros D.C., Bibi S., Sarigiannidis P.G. A Review on UAVBased Applications for Precision Agriculture. Information. 2019. Vol.10(11). N349. DOI:10.3390/info10110349 (In English).

3. Mulla D.J. Twenty-five years of remote sensing in precision agriculture: Key advances and remaining knowledge gaps. Biosystems Engineering, Special Issue: Sensing Technologies for Sustainable Agriculture. 2014. Vol. 114. N4. 358-371. DOI:10.1016/j. biosystemseng.2012.08.009 (In English).

4. Poblete-Echeverr'ia C., Fuentes S., Ortega-Farias S., GonzalezTalice J., Yuri J. A. Digital cover photography for estimating Leaf area index (LAI) in apple trees using a variable light extinction coefficient. Sensors (Switzerland). 2015. Vol.15. N.2. 2860-2872. DOI:10.3390/s150202860 (In English).

5. Kurbanov R.K., Zakharova N.I., Zakharova O.M., Gorshkov D.M. Otsenka sostoyaniya posevov ozimoy pshenitsy posle perezimovki s pomoshch'yu BPLA [Assessment of Winter Wheat after Wintering with the Use of UAVs]. Innovatsii v sel'skom khozyaystve. 2019. N3(32). 133-139 (In Russian).

6. Xu J., Gu H.B., Meng Q.M., Cheng J.H., Liu Y.H., Jiang P.A., Sheng J.D., Deng J., Bai X. Spatial pattern analysis of Haloxylon ammodendron using UAV imagery - A case study in the Gur- bantunggut Desert. International Journal of Applied Earth $\mathrm{Ob}$ DOI:10.1016/j.jag.2019.06.001 (In English).

7. Dash J.P., Pearse G.D., Watt M.S. UAV Multispectral Imagery Can Complement Satellite Data for Monitoring Forest Health. Remote Sensing. 2018. Vol. 10(8). N1216. DOI:10.3390/rs10081216 (In English).

8. Luo W., Xu X.L., Liu W., Liu M.X., Li Z.W., Peng T., Xu C.H., Zhang Y.H., Zhang R.F. UAV based soil moisture remote sensing in a karst mountainous catchment . Catena. 2019. Vol.174. 478-489. DOI:10.1016/j.catena.2018.11.017 (In English).

9. Iost F.H., Heldens W.B., Kong Z.D., de Lange E.S. Drones: Innovative Technology for Use in Precision Pest Management. Journal of Economic Entomology. 2020. Vol.113(1). 1-25. DOI:10.1093/jee/toz268 (In English).

10. Zaman-Allah M., Vergara O., Araus J.L., Tarekegne A., Magorokosho C., Zarco-Tejada P.J., Hornero A., Alba A.H., Das B., Craufurd P., Olsen M., Prasanna B.M., Cairns J. Unmanned aerial platform-based multi-spectral imaging for field phenotyping of maize. Plant Methods. 2015. Vol. 11. N35. DOI:10.1186/ s13007-015-0078-2 (In English).

11. Xue J.R., Su B.F. Significant Remote Sensing Vegetation Indices: A Review of Developments and Applications. Journal of Sensors. 2017. N1353691. DOI:10.1155/2017/1353691 (In English).

12. Artyushin A.A., Kurbanov R.K., Marchenko L.A., Zakharoservation and Geoinformation. 2019. Vol. 83. UNSP101891. 
va O.M. Vybor tiporazmernogo ryada bespilotnykh letatel'nykh apparatov i poleznoy nagruzki dlya monitoringa sel'skokhozyaystvennykh poley [The Choice of a Standard Series of Unmanned Aerial Vehicles and Payload for Monitoring Agricultural Fields]. Elektrotekhnologii i elektrooborudovanie v APK. 2019. N4(37). 36-43 (In Russian).

13. Kurbanov R.K., Zakharova O.M., Zakharova N.I., Gorshkov D.M. Programmnoe obespechenie dlya monitoringa i kontrolya pokazateley selektsionnykh protsessov posevov [Software for Monitoring and Control of Indicators of Selection Processes of Crops]. Innovatsii v sel'skom khozyaystve. 2019. N3(32). 122-132 (In Russian).

14. Guan SL, Fukami K., Matsunaka H., Okami M., Tanaka R., Nakano H., Sakai T., Nakano K., Ohdan H., Takahashi K. Assessing Correlation of High-Resolution NDVI with Fertilizer Application Level and Yield of Rice and Wheat Crops using Small UAVs. Remote Sensing. 2019. Vol. 2. N112. DOI:10.3390/ rs11020112 (In English).

15. Sidel'nik N.Ya., Pushkin A.A., Kovalevskiy S.V. Kartirovanie povrezhdennyh lesnyh nasazhdenij i ob"ektov lesohozyajstvennyh meropriyatij s ispol'zovaniem materialov kosmicheskoj s"emki i GIS-tekhnologij [Mapping of Damaged Forest Stands and Objects of Forestry Measures Using Satellite Imagery and GIS-Technologies]. Trudy BGTU. 2018. Vol.1. N1. 5-12 (In Russian).

16. Jordan C.F. Derivation of Leaf-Area Index from Quality of Light on the Forest Floor. Ecology. 1969. Vol.50. N.4. 663-666. DOI:10.2307/1936256 (In English).

17. Hashimoto N., Saito Y., Maki M., Homma K. Simulation of Reflectance and Vegetation Indices for Unmanned Aerial Vehicle (UAV) Monitoring of Paddy Fields. Remote Sensing. 2019. Vol. 11(18). N2119. DOI:10.3390/rs11182119 (In English).

18. Rouse J.W., Haas R.H., Schell J.A., Deering D.W. Monitoring vegetation systems in the Great Plains with ERTS. Third ERTS Symposium, NASA. 1973. SP-351(I). 309-317 (In English).

19. Hassan M.A., Yang M.J., Rasheed A., Yang G.J., Reynolds M., Xia X.C., Xiao Y.G., He Z.H. A rapid monitoring of NDVI across the wheat growth cycle for grain yield prediction using a multi-spectral UAV platform. Plant Science. 2019. Vol. 282(SI). 95-103. DOI:10.1016/j.plantsci.2018.10.022 (In English).

Конфликт интересов. Авторы заявляют об отсутствии конфликта интересов.
20. Fiodortsev R.V., Silie Cuenca A.R., Kozhevnikov D.A., Medina V.M., Delgado R. Application of Satellite Image Processing Methods for Hydrocarbon Field Search. Devices and Methods of Measurements. 2019. Vol. 10(4). 373-381. DOI:10.21122/2220-9506-2019-10-4-373-381 (In English).

21. Qi, J., Chehbouni A., Huete A., Kerr Y., Sorooshian S. A Modified Soil Adjusted Vegetation Index. Remote Sensing of Environment. 1994. Vol.48. 119-126 (In English).

22. Cammarano D., Fitzgerald G., Basso B., O'Leary G., Chen D., Grace P., Costanza F. Use of the Canopy Chlorophyl Content Index (CCCI) for Remote Estimation of Wheat Nitrogen Content in Rainfed Environments. Agronomy Journal. 2011. N103. 15971603. DOI:10.2134/agronj2011.0124 (In English).

23. Lu N., Wang W.H., Zhang Q.F., Li D., Yao X., Tian Y.C., Zhu Y., Cao W.X., Baret R., Liu S.Y., Cheng T. Estimation of Nitrogen Nutrition Status in Winter Wheat from Unmanned Aerial Vehicle Based Multi-Angular Multispectral Imagery. Frontiers in Plant Science. 2019. Vol. 10. N1601. DOI:10.3389/ fpls.2019.01601 (In English).

24. Vincini M., Frazzi E., D’Alessio P. A broad-band leaf chlorophyll vegetation index at the canopy scale. Precision Agriculture. 2008. Vol. 9. 303-319. DOI:10.1007/s11119-008-9075-z (In English).

25. Boegh E., Soegaard H., Broge N., Hasager C., Jensen N., Schelde K., Thomsen A. Airborne Multi-spectral Data for Quantifying Leaf Area Index, Nitrogen Concentration and Photosynthetic Efficiency in Agriculture. Remote Sensing of Environment. 2002. N81(2-3). 179-193 (In English).

26. Boiarskii B., Hasegawa H. Comparison of NDVI and NDRE Indices to Detect Differences in Vegetation and Chlorophyll Content. Journal of Mechanics of Continua and Mathematical Sciences. 2019. SI(4). 20-29. DOI:10.26782/jmcms.spl.4/2019.11.00003 (In English).

27. Lu N., Wang W.H., Zhang Q.F., Li D., Yao X., Tian Y.C., Zhu Y., Cao W.X., Baret R., Liu S.Y., Cheng T. Estimation of Nitrogen Nutrition Status in Winter Wheat from Unmanned Aerial Vehicle Based Multi-Angular Multispectral Imagery. Frontiers in Plant Science. 2019. Vol.10. N1601. DOI:10.3389/ fpls.2019.01601 (In English).

Conflict of interest. The authors declare no conflict of interest.
Статья поступила в редакцию 29.10.2020

The paper was submitted

to the Editorial Office on 29.10.2020
Статья принята к публикации 19.11.2020

The paper was accepted for publication on 19.11.2020 